\title{
GMR
}

\section{Antimicrobial activity and chemical composition of Brunfelsia uniflora flower oleoresin extracted by supercritical carbon dioxide}

L.C.T. Thiesen ${ }^{1}$ E.Y.Y. Sugauara ${ }^{1}$, V. Tešević ${ }^{2}$ J. Glamočlija ${ }^{3}$, M. Soković ${ }^{3}$ J.E. Gonçalves ${ }^{4}$, Z.C. Gazim ${ }^{1}$, G.A. Linde ${ }^{1}$ and N.B. Colauto ${ }^{1}$

${ }^{1}$ Programa de Pós-graduação em Biotecnologia Aplicada à Agricultura, Universidade Paranaense, Umuarama, PR, Brasil

${ }^{2}$ Faculty of Chemistry, University of Belgrade, Belgrade, Serbia

${ }^{3}$ Mycological Laboratory, Institute for Biological Research "Siniša Stanković", University of Belgrade, Belgrade, Serbia

${ }^{4}$ Programa de Mestrado em Tecnologias Limpas e Promoção da Saúde e Instituto Cesumar de Ciência, Tecnologia e Inovação,

Centro Universitário UniCesumar, Maringá, PR, Brasil

Corresponding author: N.B. Colauto

E-mail: nbc@unipar.br

Genet. Mol. Res. 16 (2): gmr16029548

Received November 22, 2016

Accepted February 17, 2017

Published April 13, 2017

DOI http://dx.doi.org/10.4238/gmr16029548

Copyright (C) 2017 The Authors. This is an open-access article distributed under the terms of the Creative Commons Attribution ShareAlike (CC BY-SA) 4.0 License.

ABSTRACT. Brunfelsia genus is traditionally utilized in popular
medicine due to its antibacterial and antifungal properties to name but
a few. However, studies on the antimicrobial activity of Brunfelsia
uniflora flower oleoresin have not been found yet. This study aimed
to evaluate the chemical composition and antimicrobial activity of
B. uniflora flower oleoresin obtained by supercritical carbon dioxide.
Oleoresin from the plant dried flowers was obtained by carbon dioxide,
and the chemical composition was analyzed by gas chromatographic-
mass spectrometry. The minimum inhibitory concentration (MIC),
minimum bactericidal concentration (MBC), and minimum fungicidal
concentration (MFC) of this oleoresin for seven bacteria and eight fungi

Genetics and Molecular Research 16 (2): gmr16029548 
were determined using 96-well microtiter plates. The oleoresin MBC for Bacillus cereus, Enterobacter cloacae, Escherichia coli, Listeria monocytogenes, Pseudomonas aeruginosa, Salmonella enterica, and Staphylococcus aureus ranged from 0.01 to $0.08 \mathrm{mg} / \mathrm{mL}$, whereas the controls streptomycin and ampicillin varied from 0.1 and $0.5 \mathrm{mg} /$ $\mathrm{mL}$. The oleoresin MFC for Aspergillus fumigatus, Aspergillus niger, Aspergillus ochraceus, Aspergillus versicolor, Penicillium funiculosum, Penicillium ochrochloron, Penicillium verrucosum var. cyclopium, and Trichoderma viride varied from 0.01 to $0.08 \mathrm{mg} / \mathrm{mL}$, whereas the controls bifonazole and ketoconazole ranged from 0.2 to $3.5 \mathrm{mg} /$ $\mathrm{mL}$. The oleoresin obtained by supercritical carbon dioxide presented bacteriostatic, bactericidal, fungistatic, and fungicidal activities that were higher than the positive controls streptomycin, ampicillin, bifonazole, and ketoconazole. The high antimicrobial activity was related to the high content of $(E, E)$-geranyllinalool that composes $21.0 \%$ of the oleoresin and a possible synergic action with fatty acid esters that made up $50.5 \%$ of the oleoresin. The oleoresin antimicrobial activity against common multiresistant bacteria in severe infectious processes as $P$. aeruginosa or against toxin-producing fungi such as $P$. ochrochloron or fungi that are difficult to control such as $T$. viride suggests the development of promising applications of this product in the food, farming, livestock, and pharmaceutical industry.

Key words: Minimal bacteriostatic concentration; (2E, 6Z)-farnesal; Minimal fungistatic concentration; $(E)$-nerolidol; $(E, E)$-geranyllinalool

\section{INTRODUCTION}

Brunfelsia genus comprises 50 species popularly known as lady-of-the-night, manacá, manacá-açu, jeretaca, cangambá, and Paraguayan jasmine. The species of this genus are appreciated for the exuberant effect of their chromatic variation and also for the fragrance of their flowers (Filipowicz and Renner, 2012). Brunfelsia uniflora (Pohl.) D. Don, synonym of Brunfelsia hopeana (Hook.) Benth, from the Solanaceae family, is native of the Brazilian Atlantic Forest, found in Amazon region as well as in several countries that are part of this biome such as Brazil, Bolivia, Peru, Ecuador, Colombia, and Venezuela. It is a shrub or small tree with simple leaves and purple or white individual or clustered flowers (Filipowicz and Renner, 2012).

This genus is traditionally utilized in popular medicine of American peoples, especially in the Amazon region due to its distinct and varied medicinal effects such as hallucinogenic, antiinflammatory (Castioni and Kapetanidis, 1996; Filipowicz and Renner, 2012), antibacterial, and antifungal (Begum et al., 2007) effects. However, studies on antimicrobial activity of $B$. uniflora flower oleoresin extracted by supercritical carbon dioxide were not found.

Hydrodistillation is one of the most utilized extraction processes for essential oils of leaves; however, B. uniflora flowers are sensitive to heat and heating can result in losses of volatile compounds with reduced extraction yield (Bertrand et al., 2006). Extraction by supercritical carbon dioxide has the advantage of using low temperatures, and allows controlling extraction conditions such as temperature, pressure, and solvent flow. When utilizing carbon

Genetics and Molecular Research 16 (2): gmr16029548 
dioxide as solvent, its advantage is the high extractive selectivity to obtain highly aggregated value compounds (Barros et al., 2014). Besides greater yield, the extraction by supercritical carbon dioxide is quick and does not leave organic solvent residues in the extract, which makes it an interesting technique to obtain plant extracts industrially (Mazutti et al., 2006).

Despite the use of new genomic tools, there has been a decrease in identification of new antibiotics and an increase in microorganism resistance to conventional antibiotics. The resistance to microorganisms is related to the overuse of antibiotics in livestock worldwide (Aarestrup, 2012). Common microorganisms such as Pseudomonas aeruginosa, Escherichia coli, and Listeria monocytogenes have become the main causes of hospitalizations and deaths in hospitals (Mead et al., 1999). Fungi of Aspergillus and Penicillium genera are also difficult to control in food preservation, increasing risks to human and animal health (Korsten, 2006). Therefore, the search for new alternatives to control microorganisms is necessary to produce and keep food safe, preserving human and animal health. Thus, this study aimed to evaluate the chemical composition and antimicrobial activity of $B$. uniflora flower oleoresin obtained by supercritical carbon dioxide.

\section{MATERIAL AND METHODS}

\section{Biological material}

Fresh flowers of B. uniflora were collected in the morning in the northern region of the State of Paraná, Brazil, at the coordinates $23^{\circ} 29.06{ }^{\prime} \mathrm{S} 51^{\circ} 47.30^{\prime} \mathrm{W}$ and altitude of 670 $\mathrm{m}$. Plant sample was identified and deposited in the Educational Herbarium of Paranaense University (HEUP) under the number 2855. The cultivation soil was evaluated for $\mathrm{pH}$, macroand micronutrients, and granulometry according to Camargo et al. (2009). The soil samples were collected at $20 \mathrm{~cm}$ depth from four different equidistant points $1 \mathrm{~m}$ away from the plant to obtain a compound sample (Gazim et al., 2007). This region has humid temperate climate $(\mathrm{CFa})$ according to Köppen-Geiger classification, with hot humid summer, more intense winter and without dry season, and annual average temperature of $22^{\circ}-23^{\circ} \mathrm{C}$ and monthly rainfall of 1400-1600 mm (Peel et al., 2007).

\section{Extraction of $B$. uniflora flower oleoresin by supercritical carbon dioxide}

The flowers were dried at room temperature $\left(26^{\circ} \mathrm{C}\right)$ and ground in a cutting mill. $B$. uniflora flower oleoresin was obtained by supercritical carbon dioxide. For extraction, $10 \mathrm{~g}$ flowers was transferred to a bench extractor (White Martins S.A.; Quimis) and kept in contact with supercritical carbon dioxide at $100 \mathrm{bars}, 30^{\circ} \mathrm{C}$, for $60 \mathrm{~min}$. After this time, the extraction occurred with constant flow of carbon dioxide ( $2 \mathrm{~mL} / \mathrm{min}$ ) for $3 \mathrm{~h}$ (Reverchon, 1997).

\section{Gas chromatographic-mass spectrometry chemical identification}

Gas chromatographic-mass spectrometric analysis (EI) was performed using an Agilent 5973 Network chromatograph coupled to an Agilent 5973 MSD spectrometer (Agilent Technologies, Santa Clara, CA, USA). For the separation, an Agilent 19091S-433 HP-5MS fused silica capillary column with $30 \mathrm{~m} \times 0.25 \mathrm{~mm}$ ID and $0.25-\mu \mathrm{m}$ film thickness was used. The temperature program - in the gas chromatography oven - was from $60^{\circ}$ to $285^{\circ} \mathrm{C}$ at a rate

Genetics and Molecular Research 16 (2): gmr16029548 
of $4.3^{\circ} \mathrm{C} / \mathrm{min}$. The carrier gas was helium; inlet pressure: $25 \mathrm{kPa}$; linear velocity: $1 \mathrm{~mL} / \mathrm{min}$ at $210^{\circ} \mathrm{C}$; injector temperature: $250^{\circ} \mathrm{C}$; injection mode: splitless. Mass spectrometric scan conditions were source temperature of $200^{\circ} \mathrm{C}$; interface temperature of $250^{\circ} \mathrm{C}$; E energy of 70 $\mathrm{eV}$; and mass scan range of 40-350 amu.

\section{Antibacterial activity}

The bacteria used for the antibacterial activity assay was Bacillus cereus Frankland and Frankland (clinical isolate), Enterobacter cloacae (Jordan) Hormaeche and Edwards (clinical isolate), E. coli (Migula) Castellani and Chalmers (ATCC 35218), L. monocytogenes (Murray et al.) Pirie (NCTC 7973), P. aeruginosa (Schroeter) Migula (ATCC 27853), Salmonella enterica subsp enterica (ex Kauffmann and Edwards) Le Minor and Popoff serovar Typhimurium (ATCC 13311), and Staphylococcus aureus subsp aureus Rosenbach (ATCC 6538). Microorganisms were obtained from the Mycological Laboratory, Institute for Biological Research 'Siniša Stanković', University of Belgrade, Serbia. The method used for the antibacterial activity was by microdilution (Hänel and Raether, 1988; Espinel-Ingroff, 2001). The bacterial suspension concentrations were of $1.0 \times 10^{5} \mathrm{CFU} / \mathrm{mL}$ adjusted with sterile saline solution. Inoculum was prepared daily and stored at $4^{\circ} \mathrm{C}$ until use. In order to verify the absence of contaminations, the inoculum was grown in solid medium to validate each inoculum. All experiments were in duplicate and repeated three times.

The minimum inhibitory concentration (MIC) and minimum bactericidal concentration (MBC) were determined using 96-well microtiter plates. The bacterial suspension was adjusted with sterile saline to a concentration of $1.0 \times 10^{5} \mathrm{CFU} / \mathrm{mL}$. Compounds to be investigated were dissolved in 5\% DMSO solution containing $0.1 \%$ polysorbate- $80(\mathrm{v} / \mathrm{v})(1 \mathrm{mg} / \mathrm{mL})$ and added in Luria-Bertani (LB) broth medium $\left(100 \mu \mathrm{L}\right.$ with bacterial inoculum $\left(1.0 \times 10^{4} \mathrm{CFU} /\right.$ well $)$ to achieve the wanted concentrations. The microplates were incubated at rotary shaker (160 rpm) for $24 \mathrm{~h}$ at $37^{\circ} \mathrm{C}$. The lowest concentrations without visible growth at light microscope were defined as concentrations that completely inhibited bacterial growth or MIC. The MBCs were determined by serial subcultivation of $2 \mu \mathrm{L}$ onto microtiter plates containing $100 \mu \mathrm{L}$ broth per well and further incubation for $24 \mathrm{~h}$. The lowest concentration with no visible growth was defined as the MBC, indicating $99.5 \%$ killing of the original inoculum. The optical density of each well was measured at a wavelength of $655 \mathrm{~nm}$ by Microplate Manager 4.0 (Bio-Rad Laboratories) and compared with a blank and a positive control. Streptomycin (Sigma P 7794) and ampicillin (Panfarma, Belgrade, Serbia) were used as positive controls $(1 \mathrm{mg} / \mathrm{mL}$ in sterile physiological saline). Solution of 5\% DMSO was used as a negative control. All experiments were performed in duplicate and repeated three times.

\section{Antifungal activity}

For the antifungal bioassays, eight fungi were used: Aspergillus fumigatus Fresenius (ATCC 1022), Aspergillus niger van Tieghem (ATCC 6275), Aspergillus ochraceus Wilhelm (ATCC 12066), Aspergillus versicolor (Vuillemin) Tiraboschi (ATCC 11730), Penicillium funiculosum Thom (ATCC 8725), Penicillium ochrochloron Biourge (ATCC 9112), Penicillium verrucosum var. cyclopium (Westling) Samson, Stolk \& Hadlok (food isolate), and Trichoderma viride Pers. (IAM 5061). Microorganisms were obtained from the Mycological Laboratory, Institute for Biological Research 'Siniša Stanković', University of

Genetics and Molecular Research 16 (2): gmr16029548 
Belgrade, Serbia. The micromycetes were kept on malt extract agar and the cultures stored at $4^{\circ} \mathrm{C}$ and subcultured once a month (Booth, 1971). In order to investigate the antifungal activity of the compounds, a modified microdilution technique was used (Hänel and Raether, 1988; Espinel-Ingroff, 2001). The fungal spores were washed from the surface of agar plates with sterile $0.85 \%$ saline containing $0.1 \%$ polysorbate- $80(\mathrm{v} / \mathrm{v})$. The spore suspension was adjusted with sterile saline to a concentration of approximately $1.0 \times 10^{5}$ in a final volume of $100 \mathrm{ml}$ per well. The inocula were stored at $4^{\circ} \mathrm{C}$ for further use. Dilutions of inocula were cultured on solid malt agar to verify the absence of contamination and to check the validity of each inoculum. Minimum inhibitory concentration (MIC) determinations were performed by a serial dilution technique using 96-well microtiter plates. The compounds investigated were dissolved in 5\% DMSO solution containing $0.1 \%$ polysorbate- $80(\mathrm{v} / \mathrm{v})(1 \mathrm{mg} / \mathrm{mL})$ and added in broth malt extract medium with inoculum. The microplates were incubated at rotary shaker $(160 \mathrm{rpm})$ for $72 \mathrm{~h}$ at $28^{\circ} \mathrm{C}$. The lowest concentrations without visible growth at light microscope were defined as MIC. The minimal fungicidal concentration (MFC) was determined by serial subcultivation of $2 \mu \mathrm{L}$ of tested compounds dissolved in medium and inoculated for $72 \mathrm{~h}$ onto microtiter plates containing $100 \mu \mathrm{L}$ broth per well and with further incubation for $72 \mathrm{~h}$ at $28^{\circ} \mathrm{C}$. The lowest concentration with no visible growth was defined as MFC indicating $99.5 \%$ killing of the original inoculum. Solution of 5\% DMSO was used as a negative control. Commercial fungicides bifonazole (Srbolek, Belgrade, Serbia) and ketoconazole (Zorkapharma, Šabac, Serbia) were used as positive controls $(1-3500 \mathrm{mg} / \mathrm{mL})$. All experiments were performed in duplicate and repeated three times.

\section{Statistical analysis}

All of the tests were carried out in triplicate. The results were expressed as mean values \pm standard deviation, and analyzed by one-way analysis of variance (ANOVA), followed by Tukey's HSD test with $\alpha=0.05$, to determine whether there is a statistically significant difference among the obtained results. The analysis was carried out by Statistical Package for the Social Sciences (SPSS) version 18.0.

\section{RESULTS}

The granulometric analysis of the soil showed $40.85 \%$ clay, $20.00 \%$ silt, and $39.15 \%$ sand, and the soil was classified as clayey according to Brasil (2008). High iron content (62.34 $\left.\mathrm{mg} / \mathrm{dm}^{3}\right)($ Table 1$)$ makes this soil red, highly fertile, and saturated for bases $(\mathrm{V}=79.55 \%)$ and organic matter $\left(\mathrm{OM}=35.60 \mathrm{~g} / \mathrm{dm}^{3}\right)$, but with low phosphorus content $\left(2.20 \mathrm{mg} / \mathrm{dm}^{3}\right)$.

Table 1. Analysis of $\mathrm{pH}$, macro- and micronutrients of the soil utilized in the cultivation of Brunfelsia uniflora.

\begin{tabular}{|c|c|c|c|c|c|c|c|c|}
\hline \multicolumn{9}{|c|}{$\mathrm{pH}$ and macronutrients } \\
\hline & \multicolumn{6}{|c|}{$\left(\mathrm{cmol} / \mathrm{dm}^{3}\right)$} & \multicolumn{2}{|c|}{$\left(\mathrm{mg} / \mathrm{dm}^{3}\right)$} \\
\hline $\mathrm{pH}\left(\mathrm{CaCl}_{2}\right)$ & $\mathrm{Al}^{3+}$ & $\mathrm{H}^{+}+\mathrm{Al}^{3+}$ & $\mathrm{Ca}^{2+} \mathrm{Mg}^{2+}$ & $\mathrm{K}^{+}$ & SB & CTC & $P$ & $\mathrm{C}$ \\
\hline 6.22 & 0.0 & 3.42 & 13.00 & 0.31 & 13.31 & 16.73 & 2.20 & 20.65 \\
\hline \multicolumn{9}{|c|}{ Micronutrients $\left(\mathrm{cmol} / \mathrm{dm}^{3}\right)$} \\
\hline $\mathrm{V}(\%)$ & $\mathrm{Ca}$ & \multicolumn{2}{|c|}{$\mathrm{Mg}$} & $\mathrm{K}$ & $\mathrm{Ca} / \mathrm{Mg}$ & \multicolumn{2}{|c|}{$\mathrm{Ca} / \mathrm{K}$} & $\mathrm{Mg} / \mathrm{K}$ \\
\hline 79.55 & 8.75 & \multicolumn{2}{|c|}{4.25} & 0.31 & 2.06 & \multicolumn{2}{|c|}{28.44} & 13.81 \\
\hline
\end{tabular}

The chemical composition of $B$. uniflora flower oleoresin by supercritical carbon dioxide resulted in 50 compounds (Table 2). The predominant class was oxygenated diterpene

Genetics and Molecular Research 16 (2): gmr16029548 
$(E, E)$-geranyllinalool $(21.0 \%)$, followed by oxygenated sesquiterpenes $(E)$-nerolidol $(3.9 \%)$ and $(2 E, 6 Z)$-farnesal $(0.5 \%)$. Also, a great amount of fatty acid esters was extracted $(48.2 \%)$, making the presence of hydrocarbons $(15.3 \%)$ evident, which is typical of oleoresin extraction technique (Table 2).

Table 2. Chemical composition of Brunflesia uniflora flower oleoresin extracted by supercritical carbon dioxide.

\begin{tabular}{|c|c|c|c|c|}
\hline Peak & Compound & RI & Area (\%) & Methods of identification \\
\hline 1 & Camphor & 1134 & $\mathrm{t}$ & a.b. \\
\hline 2 & n.i. & 1382 & 0.4 & a.b. \\
\hline 3 & n.i. & 1387 & 1.6 & a.b. \\
\hline 4 & $(E)$-nerolidol & 1577 & 3.9 & a.b. \\
\hline 5 & Dodecyl acrylate & 1694 & 0.2 & a.b. \\
\hline 6 & $(2 E, 6 Z)$-farnesal & 1723 & 0.5 & a.b. \\
\hline 7 & Hexadecanoic acid & 1977 & 0.5 & a.b. \\
\hline 8 & $(E, E)$-geranyllinalool & 2040 & 21.0 & a.b. \\
\hline 9 & n.i. & 2461 & 0.1 & a.b. \\
\hline 10 & Tricosane & 2305 & 0.1 & a.b. \\
\hline 11 & n.i. & 2485 & 0.2 & a.b. \\
\hline 12 & Pentacosane & 2501 & 0.4 & a.b. \\
\hline 13 & 1,3-dihydroxy propan-2-yl hexadecanoate & 2518 & 0.5 & a.b. \\
\hline 14 & n.i. & 2638 & 0.1 & a.b. \\
\hline 15 & Eicosanoic acid, isoamyl ester & 2654 & 0.2 & a.b. \\
\hline 16 & Phenyl palmitate & 2681 & 0.3 & a.b. \\
\hline 17 & n.i. & 2688 & 0.1 & a.b. \\
\hline 18 & 1-tetracosanol & 2701 & 0.8 & a.b. \\
\hline 19 & Heptacosane & 2701 & 1.3 & a.b. \\
\hline 20 & Octadecanoic acid, 2,3-dihydroxypropyl ester & 2724 & 0.8 & a.b. \\
\hline 21 & ( & 2746 & 0.8 & a.b. \\
\hline 22 & Eicosanoic acid, hexyl ester & 2809 & 0.2 & a.b. \\
\hline 23 & Octacosane & 2801 & 0.3 & a.b. \\
\hline 24 & Hexacosyl acetate & 2809 & 0.1 & a.b. \\
\hline 25 & Docosanoic acid, isoamyl ester & 2844 & 2.3 & a.b. \\
\hline 26 & Nonacosane & 2902 & 4.9 & a.b. \\
\hline 27 & n.i. & 2916 & 0.3 & a.b. \\
\hline 28 & n.i. & 2933 & 0.6 & a.b. \\
\hline 29 & Docosanoic acid hexyl ester & 2966 & 6.2 & a.b. \\
\hline 30 & Eicosanoic acid phenylmethyl ester & 2974 & 0.4 & a.b. \\
\hline 31 & Tetracosanoic acid isoamyl ester & 3022 & 5.5 & a.b. \\
\hline 32 & Tricosanoic acid hexyl ester & 3049 & 0.4 & a.b. \\
\hline 33 & Untriacontane & 3100 & 4.8 & a.b. \\
\hline 34 & Docosanoic acid octyl ester & 3129 & 1.2 & a.b. \\
\hline 35 & Tetracosanoic acid hexyl ester & 3138 & 10.4 & a.b. \\
\hline 36 & Docosanoic acid phenylmethyl ester & 3150 & 2.5 & a.b. \\
\hline 37 & Hexacosanoic acid isoamyl ester & 3187 & 0.8 & a.b. \\
\hline 38 & Tetracosanoic acid 3-methylhexyl ester & 3193 & 0.7 & a.b. \\
\hline 39 & Tricosanoic acid phenylmethyl ester & 3224 & 1.7 & a.b. \\
\hline 40 & Tetracosanoic acid octyl ester & 3231 & 0.6 & a.b. \\
\hline 41 & n.i. & 3246 & 0.6 & a.b. \\
\hline 42 & Hexacosanoic acid hexyl ester & 3288 & 2.3 & a.b. \\
\hline 43 & Tetracosanoic acid phenylmethyl ester & 3295 & 4.6 & a.b. \\
\hline 44 & Tritriacontane & 3305 & 3.5 & a.b. \\
\hline 45 & Octacosanoic acid octyl ester & 3439 & 1.7 & a.b. \\
\hline 46 & Hexacosanoic acid hexyl ester & 3445 & 3.1 & a.b. \\
\hline 47 & Pentacosanoic acid phenylmethyl ester & 3486 & 0.5 & a.b. \\
\hline 48 & Octacosanoic acid octyl ester & 3612 & 0.9 & a.b. \\
\hline 49 & Tricontanoic acid hexyl ester & 3618 & 0.9 & a.b. \\
\hline 50 & Tricontanoic acid octyl ester & 3839 & 0.3 & a.b. \\
\hline \multicolumn{3}{|c|}{ Total identified } & 96.1 & - \\
\hline
\end{tabular}

$\mathrm{a}=$ identification based on retention index (RI); $\mathrm{b}=$ identification based on comparison of mass spectra; n.i. = unidentified compound; $\mathrm{t}=$ trace. Compound listed in order of elution from an HP-5MS column.

The bacteriostatic activity (MIC) for oleoresin varied from 0.005 to $0.04 \mathrm{mg} / \mathrm{mL}$, whereas the positive controls streptomycin and ampicillin had MIC values ranging from 0.05

Genetics and Molecular Research 16 (2): gmr16029548 
to $0.5 \mathrm{mg} / \mathrm{mL}$. Thus, MIC values for B. uniflora oleoresin were in general effective and lower $(\mathrm{P} \leq 0.05)$ than the respective positive controls (Table 3$)$. Oleoresin also presented greater bactericidal activity than the positive controls. MBC values ranged from 0.01 to $0.08 \mathrm{mg} / \mathrm{mL}$ for oleoresin, and from 0.1 to $0.5 \mathrm{mg} / \mathrm{mL}$ for the positive controls streptomycin and ampicillin (Table 3).

Table 3. Minimum inhibitory concentration (MIC) and minimum bactericidal concentration (MBC) of Brunfelsia uniflora oleoresin, streptomycin, and ampicillin.

\begin{tabular}{l|c|c|c|c|c|c}
\hline \multirow{2}{*}{ Bacterium } & \multicolumn{2}{|c|}{ Brunfelsia uniflora $(\mathrm{mg} / \mathrm{mL})$} & Streptomycin $(\mathrm{mg} / \mathrm{mL})$ & \multicolumn{2}{c|}{ Ampicillin $(\mathrm{mg} / \mathrm{mL})$} \\
\cline { 2 - 7 } & MIC & MBC & MIC & MIC & MBC \\
\hline Bacillus cereus & $0.0050 \pm 0.0003^{\mathrm{A}}$ & $0.0100 \pm 0.0060^{\mathrm{a}}$ & $0.0500 \pm 0.0300^{\mathrm{B}}$ & $0.1000 \pm 0.0300^{\mathrm{b}}$ & $0.1000 \pm 0.0100^{\mathrm{C}}$ & $0.1500 \pm 0.0300^{\mathrm{b}}$ \\
\hline Enterobacter cloacae & $0.0400 \pm 0.0060^{\mathrm{A}}$ & $0.0400 \pm 0.0000^{\mathrm{a}}$ & $0.500 \pm 0.001^{\mathrm{C}}$ & $0.1000 \pm 0.0600^{\mathrm{b}}$ & $0.300 \pm \pm 0.0200^{\mathrm{B}}$ & $0.5000 \pm 0.090^{\mathrm{C}}$ \\
\hline Escherichia coli & $0.0100 \pm 0.0020^{\mathrm{A}}$ & $0.0200 \pm 0.020^{\mathrm{a}}$ & $0.1500 \pm 0.0300^{\mathrm{B}}$ & $0.3000 \pm 0.0300^{\mathrm{b}}$ & $0.1500 \pm 0.0001^{\mathrm{B}}$ & $0.3000 \pm 0.0300^{\mathrm{b}}$ \\
\hline Listeria monocytogenes & $0.0050 \pm 0.0003^{\mathrm{A}}$ & $0.0200 \pm 0.0001^{\mathrm{a}}$ & $0.2500 \pm 0.0600^{\mathrm{C}}$ & $0.5000 \pm 0.0300^{\mathrm{C}}$ & $0.1000 \pm 0.0300^{\mathrm{B}}$ & $0.1500 \pm 0.0100^{\mathrm{b}}$ \\
\hline Pseudomonas aeruginosa & $0.0400 \pm 0.0001^{\mathrm{A}}$ & $0.0800 \pm 0.0100^{\mathrm{a}}$ & $0.0500 \pm 0.0100^{\mathrm{A}}$ & $0.1000 \pm 0.0300^{\mathrm{b}}$ & $0.1000 \pm 0.0600^{\mathrm{B}}$ & $0.2000 \pm 0.0100^{\mathrm{C}}$ \\
\hline Salmonella enterica & $0.0100 \pm 0.0030^{\mathrm{A}}$ & $0.0400 \pm 0.0001^{\mathrm{a}}$ & $0.0500 \pm 0.0300^{\mathrm{B}}$ & $0.1000 \pm 0.0001^{\mathrm{b}}$ & $0.1500 \pm 0.0100^{\mathrm{C}}$ & $0.2000 \pm 0.0001^{\mathrm{C}}$ \\
\hline Staphylococcus aureus & $0.0100 \pm 0.0001^{\mathrm{A}}$ & $0.0200 \pm 0.0030^{\mathrm{a}}$ & $0.1250 \pm 0.0300^{\mathrm{B}}$ & $0.2500 \pm 0.0600^{\mathrm{C}}$ & $0.1000 \pm 0.0300^{\mathrm{B}}$ & $0.1500 \pm 0.0100^{\mathrm{b}}$ \\
\hline
\end{tabular}

Different superscript capital letters and small case letters on the same column indicate statistical differences among the treatments according to Tukey's test $(\mathrm{P} \leq 0.05)$.

Moreover, B. uniflora oleoresin had action against P. aeruginosa (MIC of 0.0400 $\mathrm{mg} / \mathrm{mL}$ and $\mathrm{MBC}$ of $0.0800 \mathrm{mg} / \mathrm{mL}$ ). This is a common multiresistant bacterium in serious infectious processes in animals and humans (Magiorakos et al., 2012). Oleoresin action against $P$. aeruginosa was greater than the controls streptomycin (MIC of $0.0500 \mathrm{mg} / \mathrm{mL}$ and MBC of $0.1000 \mathrm{mg} / \mathrm{mL}$ ) and ampicillin (MIC of $0.1000 \mathrm{mg} / \mathrm{mL}$ and $\mathrm{MBC}$ of $0.2000 \mathrm{mg} / \mathrm{mL}$ ). It was also verified that Gram-positive bacteria were more sensitive to oleoresin than Gram-negative ones. For B. cereus, S. aureus, and L. monocytogenes, the MBC values were 0.0100, 0.0200, and $0.0200 \mathrm{mg} / \mathrm{mL}$, respectively. For E. coli, E. cloacae, and S. enterica, however, the MBC values were greater, $0.0200,0.0400$, and $0.0400 \mathrm{mg} / \mathrm{mL}$, respectively (Table 3).

The fungistatic activity (MIC) for oleoresin varied from 0.0012 to $0.04 \mathrm{mg} / \mathrm{mL}$, but for the positive controls bifonazole and ketoconazole the MIC values varied from 0.1 to $2.5 \mathrm{mg}$ / $\mathrm{mL}$. Thus, the MIC values for $B$. uniflora oleoresin were smaller $(\mathrm{P} \leq 0.05)$ than the positive controls (Table 4). Oleoresin also showed greater fungicidal activity than the positive controls. MFC values ranged from 0.01 to $0.08 \mathrm{mg} / \mathrm{mL}$ for oleoresin and from 0.2 to $3.5 \mathrm{mg} / \mathrm{mL}$ for the positive controls bifonazole and ketoconazole (Table 4).

Table 4. Minimum inhibitory concentration (MIC) and minimum fungicidal concentration (MFC) of Brunfelsia uniflora oleoresin, bifonazole, and ketoconazole.

\begin{tabular}{|c|c|c|c|c|c|c|}
\hline \multirow[t]{2}{*}{ Fungus } & \multicolumn{2}{|c|}{ Brunfelsia uniflora $(\mathrm{mg} / \mathrm{mL})$} & \multicolumn{2}{|c|}{ Bifonazole $(\mathrm{mg} / \mathrm{mL})$} & \multicolumn{2}{|c|}{ Ketoconazole $(\mathrm{mg} / \mathrm{mL})$} \\
\hline & MIC & MFC & MIC & MFC & MIC & MFC \\
\hline Aspergillus fumigatus & $0.0200 \pm 0.0060^{\mathrm{A}}$ & $0.0400 \pm 0.0001^{a}$ & $0.1500 \pm 0.0300^{\mathrm{b}}$ & $0.2000 \pm 0.0100^{\mathrm{b}}$ & $0.2000 \pm 0.0300^{\mathrm{C}}$ & $0.5000 \pm 0.0001^{\circ}$ \\
\hline Aspergillus niger & $0.0400 \pm .0 .0020^{A}$ & $0.0800 \pm 0.0060^{\mathrm{a}}$ & $0.1000 \pm 0.0300^{\mathrm{B}}$ & $0.2000 \pm 0.0600^{\mathrm{b}}$ & $0.2000 \pm 0.0300^{\mathrm{C}}$ & $0.3000 \pm 0.0001$ \\
\hline Aspergillus ochraceus & $0.0400 \pm 0.0010^{\mathrm{A}}$ & $0.0800 \pm 0.0030^{\mathrm{a}}$ & $0.1500 \pm 0.0100^{\mathrm{B}}$ & $0.2000 \pm 0.0001^{\mathrm{b}}$ & $0.1500 \pm 0.0100^{c}$ & $0.2000 \pm 0.0300^{\mathrm{h}}$ \\
\hline Aspergillus versicolor & $0.0100 \pm 0.0001^{\mathrm{A}}$ & $0.0400 \pm 0.0030^{\mathrm{a}}$ & $0.1000 \pm 0.0300^{\mathrm{B}}$ & $0.2000 \pm 0.0001^{\mathrm{b}}$ & $0.2000 \pm 0.0300^{\mathrm{C}}$ & $0.5000 \pm 0.0100^{\circ}$ \\
\hline Penicillium verrucosum & $0.0400 \pm 0.0030^{A}$ & $0.0800 \pm 0.0010^{\mathrm{a}}$ & $0.1500 \pm 0.0600^{\mathrm{B}}$ & $0.2000 \pm 0.0001^{b}$ & $0.2000 \pm 0.0600^{\mathrm{C}}$ & $0.5000 \pm 0.0600^{\mathrm{c}}$ \\
\hline Penicillium ochrochloron & $0.0012 \pm 0.0001^{\mathrm{A}}$ & $0.0100 \pm 0.0001^{\mathrm{a}}$ & $0.2000 \pm 0.0001^{\mathrm{B}}$ & $0.2500 \pm 0.0300^{\mathrm{b}}$ & $2.5000 \pm 0.3300^{\mathrm{C}}$ & $3.5000 \pm 0.0600^{\circ}$ \\
\hline Penicillium funiculosum & $0.0025 \pm 0.0003^{\mathrm{A}}$ & $0.0500 \pm 0.0030^{\mathrm{a}}$ & $0.2000 \pm 0.0300^{\mathrm{B}}$ & $0.2500 \pm 0.0200^{\mathrm{b}}$ & $0.2000 \pm 0.0001^{\mathrm{B}}$ & $0.5000 \pm 0.0100^{\circ}$ \\
\hline Trichoderma viride & $0.0200 \pm 0.0001^{\mathrm{A}}$ & $0.0400 \pm 0.0020^{\mathrm{a}}$ & $0.1500 \pm 0.0001^{\mathrm{A}}$ & $0.2000 \pm 0.0100^{\mathrm{b}}$ & $1.0000 \pm 0.0100^{\mathrm{B}}$ & $1.0000 \pm 0.0200^{\circ}$ \\
\hline
\end{tabular}

Different superscript capital letters and small case letters on the same column indicate statistical differences among the treatments according to Tukey's test $(\mathrm{P} \leq 0.05)$.

In general, the antifungal activity for oleoresin was greater than the controls bifonazole and ketoconazole (Table 4). It is noteworthy to point out the fungicidal activity against $P$.

Genetics and Molecular Research 16 (2): gmr16029548 
ochrochloron and T. viride. For these fungi, the MFC values for oleoresin were 0.01 and $0.04 \mathrm{mg} /$ $\mathrm{mL}$, respectively, while they varied from 0.2500 to $0.2000 \mathrm{mg} / \mathrm{mL}$ for bifonazole and from 3.5000 to $1.0000 \mathrm{mg} / \mathrm{mL}$ for ketoconazole. Thus, the fungicidal action of oleoresin against $P$. ochrochloron was 25 and 350 times greater than bifonazole and ketoconazole, respectively. Against $T$. viride the oleoresin was 5 and 25 times more efficient than the respective positive controls. These results show that $B$. uniflora flower oleoresin has high activity against bacteria and fungi.

\section{DISCUSSION}

According to Morais (2009), abiotic factors such as temperature, rainfall, luminosity, and soil composition affect the chemical composition of plant secondary metabolites. Although $B$. uniflora cultivation soil is fertile, there was low phosphorus content $(2.20 \mathrm{mg} /$ $\mathrm{dm}^{3}$ ) (Table 1). Prado et al. (2005) stated that phosphorus is a structural compound of nucleic acids, coenzymes, phosphoproteins, and phospholipids, and could interfere in the oleoresin chemical composition.

The chemical composition of $B$. uniflora flower oleoresin main compound was $(E, E)$ geranyllinalool $(21.0 \%)$ (Table 2$)$. The class of oxygenated diterpenes, mainly geranyllinalool, comprises floral aroma of plants that exhale smells (Falara et al., 2014). Geranyllinalool is utilized as flavoring in food, cosmetic, and perfume industry (Lapczynski et al., 2008). It is estimated that $100 \mathrm{~kg}$ of this compound is commercialized annually worldwide (Lapczynski et al., 2008). This compound has antispasmodic activity, is used against amenorrhea, rheumatism (Zrira et al., 2008), acne, arthritis, burning, ulcers, and is also used as expectorant and antithermal (Xie et al., 2013).

In the season of the year when there are high temperatures and heavy rainfall, Brunfelsia genus has great flower production (Filipowicz and Renner, 2012). Castioni and Kapetanidis (1996) obtained 0.07\% essential oil yield from Brunfelsia grandiflora aerial part by steam distillation, obtaining more than 200 compounds. Studies carried out by our research group show that the yield of $B$. uniflora flower oleoresin obtained by supercritical carbon dioxide varies from 0.83 to $1.03 \%$. However, according to Jorge (2016) the essential yield oil of $B$. uniflora by hydrodistillation is close to zero.

The amount of $(E, E)$-geranyllinalool of $21.0 \%$ obtained from $B$. uniflora flowers by supercritical carbon dioxide is greater than the ones found by hydrodistillation extraction of Arnica montana of 14.7\% (Judžentienè and Būdienè, 2009), Heliotropium stenophyllum of 6.81\% (Urzúa et al., 2013), Exocarpium citri grandis of 3.5\% (Xie et al., 2013), but similar to Ammi visnaga of $22.7 \%$, extracted by supercritical carbon dioxide (Zrira et al., 2008). Considering a greater extraction yield of supercritical carbon dioxide when compared to hydrodistillation and the high concentration of geranyllinalool in B. uniflora flower oleoresin, this is a good alternate source of this compound.

Oleoresin of $B$. uniflora is a potential source of geranyllinalool, but the concentration of chemical compounds of essential oils could vary according to flower stage (Bertrand et al., 2006), soil composition (Gazim et al., 2007), and extraction technique (Bertrand et al., 2006). Jorge (2016) reported that the pressure increase from 150 to 200 bars of supercritical carbon dioxide increases the extraction of geranyllinalool from 11.72 to $21.52 \%$ in oleoresin. Zrira et al. (2008) reported that extraction yield of $A$. visnaga oleoresin was greater $(1.5 \%)$ by supercritical carbon dioxide when compared to hydrodistillation $(0.4 \%)$. Moreover, the geranyllinalool percentage was $22.7 \%$ in oleoresin, and it was not identified in oils obtained

Genetics and Molecular Research 16 (2): gmr16029548 
by other extraction methods. Besides a greater extraction yield, supercritical carbon dioxide preserves thermolabile compounds of the essential oil (Mazutti et al., 2006). This method also has extraction process variables such as pressure, extraction, temperature, fluid flow, extraction time, particle size, among others that could affect extraction yield of a single compound of the mixture such as geranyllinalool (Zorca et al., 2006).

The great antimicrobial potential of $B$. uniflora (Tables 3 and 4) against the evaluated microorganisms must probably be due to the presence of high concentration of geranyllinalool $(21.0 \%)$ associated with high concentrations of fatty acid esters (50.5\%). Zrira et al. (2008) reported that $A$. visnaga essential oil with $22.7 \%$ geranyllinalool showed inhibitory halos from 10 to $33 \mathrm{~mm}$ against $E$. coli, S. aureus, Klebsiella pneumoniea, Proteus mirabilis, B. subtilus, Salmonella sp, and P. aeruginosa (Feirouz and Salima, 2014). A. montana with 14.7\% geranyllinalool showed from 10 to $18 \mathrm{~mm}$ of inhibitory halo against $P$. aeruginosa, which is resistant to most studied compounds (Lister et al., 2009). In our study, B. uniflora flower oleoresin presented MIC of $0.04 \mathrm{mg} / \mathrm{mL}$ and $\mathrm{MBC}$ of $0.08 \mathrm{mg} / \mathrm{mL}$ against $P$. aeruginosa. Therefore, B. uniflora oleoresin was highly efficient (MIC $0.04 \mathrm{mg} / \mathrm{mL}$ ) against $P$. aeruginosa, a common multiresistant bacterium in severe infectious processes (Magiorakos et al., 2012).

The composition of B. uniflora oleoresin showed a variety of chemical compounds, having geranyllinalool as the main compound and more than $50 \%$ of fatty acid esters. Methyl esters present antimicrobial activity against different bacteria and fungi: E. coli, P. aeruginosa, S. aureus, A. niger, and A. fumigatus (Agoramoorthy et al., 2007; Chandrasekaran et al., 2008). Shen et al. (2012) verified that a series of 3-(2-furyl) acrylate monosaccharide esters and menthyloxycarbonyl monosaccharide esters synthesized in laboratory showed antifungal activity against A. flavus, A. niger, A. fumigatus, Geotrichum candidum and antibacterial activity against $B$. subtilis, S. aureus, Staphylococcus epidermidis, E. coli, and P. aeruginosa. Although the mechanism used by methyl esters to kill microorganisms is unknown, they might penetrate the peptideoglucan network of the cellular wall of these organisms (bacteria and fungi) and reach the cellular membrane causing its disintegration. Besides this action, esters make the transport of bioactive molecules easier and, thus, act sinergically for the bactericidal and fungicidal action (Karlová et al., 2010).

For fungi like $P$. ochrochloron, $B$. uniflora oleoresin showed efficiency with MIC of $0.0025 \mathrm{mg} / \mathrm{mL}$. For Ristíc et al. (2000), Phlomis fruticosa essential oil was not effective for this fungus. Džamić et al. (2008) reported MIC of $25 \mu \mathrm{g} / \mathrm{mL}$ for Salvia sclarea essential oil. For $T$. viride, the obtained MIC in our study was $0.02 \mathrm{mg} / \mathrm{mL}$. The MIC of essential oils for $T$. viride described in the literature is $0.6 \mathrm{mg} / \mathrm{mL}$ for Lippia alba (Glamočlija et al., 2011), $40 \mu \mathrm{L} /$ $\mathrm{mL}$ for L. nobilis, $10 \mu \mathrm{L} / \mathrm{mL}$ for Sassafras albidum (Simić et al., 2004). Therefore, B. uniflora has great fungicidal action against $P$. ochrochloron and T. viride. Fungi from Trichoderma genus are the most common contaminants of mushroom cultivations and cause great economic losses worldwide (Castle et al., 1998; Glamočlija et al., 2011). Although commonly used synthetic fungicides are efficient and have low cost, studies suggest that they leave residual toxicity that may cause side effects, including carcinogenesis and teratogenesis (McCarroll et al., 2002; Glamočlija et al., 2011). Thus, B. uniflora flower oleoresin can be explored to the development of products to control fungi and bacteria.

\section{CONCLUSIONS}

Oleoresin of B. uniflora flower extracted by supercritical carbon dioxide presents

Genetics and Molecular Research 16 (2): gmr16029548 
higher bacteriostatic, bactericidal, fungistatic, and fungicidal activity than the positive controls streptomycin, ampicillin, bifonazole, and ketoconazole. The high antimicrobial activity of the oleoresin is related to the higher content of $(E, E)$-geranyllinalool $(21.0 \%)$ and possible synergic action with fatty acid esters $(48.2 \%)$. The antimicrobial activity of $B$. uniflora oleoresin against common multiresistant bacteria in severe infectious processes such as $P$. aeruginosa or against toxin-producing fungi such as $P$. ochrochloron or fungi that are difficult to control as $T$. viride suggests the development of promising applications of this product in the food, farming, livestock, and pharmaceutical industry.

\section{ACKNOWLEDGMENTS}

The authors thank the Paranaense University, the Postgraduate Program in Biotechnology Applied to Agriculture, Coordenação de Aperfeiçoamento de Pessoal de Nível Superior (CAPES), and Conselho Nacional de Desenvolvimento Científico e Tecnológico (CNPq) for the fellowship and financial support in Brazil, and the fellowship and the Ministry of Education, Science and Technological Development of Serbia (grants \#173032 and \#172053).

\section{REFERENCES}

Aarestrup F (2012). Sustainable farming: Get pigs off antibiotics. Nature 486: 465-466. http://dx.doi.org/10.1038/486465a

Agoramoorthy G, Chandrasekaran M, Venkatesalu V and Hsu MJ (2007). Antibacterial and antifungical activities of fatty acid methyl esters of the blind-your-eye mangrove from India. Braz. J. Microbiol. 38: 739-742. http://dx.doi. org $10.1590 / \mathrm{S} 1517-83822007000400028$

Barros NA, Assis AR and Mendes MF (2014). Basil oil extraction using supercritical fluid experimental and mathematical analysis. Cienc. Rural 44: 1499-1505. http://dx.doi.org/10.1590/0103-8478cr20130917

Begum R, Rahman MS, Chowdhury AMS and Rashid M (2007). Preliminary antimicrobial activity and cytotoxicity of Brunfelsia latifolia. Dhaka Univ. J. Pharm. 6: 65-67.

Bertrand C, Comte G and Piola F (2006). Solid-phase microextraction of volatile compounds from flowers of two Brunfelsia species. Biochem. Syst. Ecol. 34: 371-375. http://dx.doi.org/10.1016/j.bse.2005.12.005

Booth C (1971). Fungal culture media. In: Methods in microbiology (Norris JR and Ribbons DW, eds.). Elsevier, New York, 49-94.

Brasil (2008). Ministério da Agricultura, Pecuária e Abastecimento. Secretaria de Política Agrícola. Classificação dos tipos de solo. Instrução Normativa n. 2, de 9 de outubro de 2008. Available at [http://extranet.agricultura.gov.br/sislegisconsulta/consultarLegislacao.do?operacao=visualizar\&id=19125].

Camargo AO, Moniz AC, Jorge JA and Valadares JMAS (2009). Métodos de análise química, mineralógica e física de solos do instituto agronômico de Campinas. 1st edn. Boletim Técnico 106. Instituto Agronômico de Campinas, Campinas.

Castioni P and Kapetanidis I (1996). Volatile constituents from Brunfelsia grandiflora ssp. grandiflora: qualitative analysis by GC-MS. Sci. Pharm. 64: 83-91.

Castle A, Speranzini D, Rghei N, Alm G, et al. (1998). Morphological and molecular identification of Trichoderma isolates on North American mushroom farms. Appl. Environ. Microbiol. 64: 133-137.

Chandrasekaran M, Kannathasan K and Venkatesalu V (2008). Antimicrobial activity of fatty acid methyl esters of some members of Chenopodiaceae. Z. Naturforsch., C, J. Biosci. 63: 331-336. http://dx.doi.org/10.1515/znc-2008-5-604

Džamić A, Soković M, Ristić M, Jovanović SG, et al. (2008). Chemical composition and antifungal activity of Salvia sclarea (Lamiaceae) essential oil. Arch. Biol. Sci. 60: 233-237. http://dx.doi.org/10.2298/ABS0802233D

Espinel-Ingroff A (2001). In vitro fungicidal activities of voriconazole, itraconazole, and amphotericin B against opportunistic moniliaceous and dematiaceous fungi. J. Clin. Microbiol. 39: 954-958. http://dx.doi.org/10.1128/ JCM.39.3.954-958.2001

Falara V, Alba JM, Kant MR, Schuurink RC, et al. (2014). Geranyllinalool synthases in solanaceae and other angiosperms constitute an ancient branch of diterpene synthases involved in the synthesis of defensive compounds. Plant Physiol. 166: 428-441. http://dx.doi.org/10.1104/pp.114.243246

Genetics and Molecular Research 16 (2): gmr16029548 
Feirouz B and Salima KG (2014). Antibacterial activity and chemical composition of Ammi visnaga L. essential oil collected from Boumerdes (Algeria) during three periods of the plant growth. J. Essent. Oil Bear. Plants 17: 13171328. http://dx.doi.org/10.1080/0972060X.2014.912164

Filipowicz N and Renner SS (2012). Brunfelsia (Solanaceae): a genus evenly divided between South America and radiations on Cuba and other Antillean islands. Mol. Phylogenet. Evol. 64: 1-11. http://dx.doi.org/10.1016/j.ympev.2012.02.026

Gazim ZC, Ferreira GA, Rezende CM, Nakamura CV, et al. (2007). Chemical compounds of the Calendula officinalis volatile fraction produced in the Paraná State, Brazil. Hortic. Bras. 25: 118-121. http://dx.doi.org/10.1590/S0102$\underline{05362007000100024}$

Glamočlija J, Soković M, Tešević V, Linde GA, et al. (2011). Chemical characterization of Lippia alba essential oil: an alternative to control green molds. Braz. J. Microbiol. 42: 1537-1546.

Hänel H and Raether W (1988). A more sophisticated method of determining the fungicidal effect of water-insoluble preparations with a cell harvester, using miconazole as an example. Mycoses 31: 148-154. http://dx.doi. org/10.1111/j.1439-0507.1988.tb03718.x

Jorge LF (2016). Antioxidant activity of chemical composition of Brunfelsia uniflora oil from its leaves and flowers obtained from $\mathrm{CO}_{2}$ supercritical. Master's thesis, Paranaense University, Umuarama. Available at [http://seshat.unipar.br/ trabalho/atividade-antioxidante-e-composicao-quimica-do-oleo-das-folhas-e-flores-de-brunfelsia-uniflora-obtid/].

Judžentienė A and Būdienè J (2009). Analysis of the chemical composition of flower essential oils from Arnica montana of Lithuanian origin. Chemija 20: 190-194.

Karlová T, Polàkovà L, Šmidrkal J and Filip V (2010). Antimicrobial effects of fatty acid fructose esters. Czech J. Food Sci. 28: 146-149.

Korsten L (2006). Advances in control of postharvest diseases in tropical fresh produce. Int. J. Postharvest Technol. Innov. 1: 48-61. http://dx.doi.org/10.1504/IJPTI.2006.009181

Lapczynski A, Bhatia SP, Letizia CS and Api AM (2008). Fragrance material review on geranyl linalool. Food Chem. Toxicol. 46 (Suppl 11): S176-S178. http://dx.doi.org/10.1016/j.fct.2008.06.050

Lister PD, Wolter DJ and Hanson ND (2009). Antibacterial-resistant Pseudomonas aeruginosa: clinical impact and complex regulation of chromosomally encoded resistance mechanisms. Clin. Microbiol. Rev. 22: 582-610. http:// dx.doi.org/10.1128/CMR.00040-09

Magiorakos AP, Srinivasan A, Carey RB, Carmeli Y, et al. (2012). Multidrug-resistant, extensively drug-resistant and pandrug-resistant bacteria: an international expert proposal for interim standard definitions for acquired resistance. Clin. Microbiol. Infect. 18: 268-281. http://dx.doi.org/10.1111/j.1469-0691.2011.03570.x

Mazutti M, Beledelli B, Mossi AJ, Cansian RL, et al. (2006). Chemical characterization of Ocimum basilicum L. extracts obtained by high pressure $\mathrm{CO}_{2}$ extraction. Quim. Nova 29: 1198-1202. http://dx.doi.org/10.1590/S0100$\underline{40422006000600010}$

McCarroll NE, Protzel A, Ioannou Y, Frank Stack HF, et al. (2002). A survey of EPA/OPP and open literature on selected pesticide chemicals. III. Mutagenicity and carcinogenicity of benomyl and carbendazim. Mutat. Res. 512: 1-35. http://dx.doi.org/10.1016/S1383-5742(02)00026-1

Mead PS, Slutsker L, Dietz V, McCaig LF, et al. (1999). Food-related illness and death in the United States. Emerg. Infect. Dis. 5: 607-625. http://dx.doi.org/10.3201/eid0505.990502

Morais LAS (2009). Influência dos fatores abióticos na composição química dos óleos essenciais. Hortic. Bras. 27 : S4050-S4063.

Peel MC, Finlayson BL and Mcmahon TA (2007). Updated world map of the Köppen-Geiger climate classification. Hydrol. Earth Syst. Sci. 11: 1633-1644. http://dx.doi.org/10.5194/hess-11-1633-2007

Prado RM, Vale DW and Romualdo LM (2005). Phosphorus application to the nutritional status and dry matter production of passion fruit cuttings. Acta Sci. Agron. 27: 493-498.

Reverchon E (1997). Supercritical fluid extraction and fractionation of essential oils and related products. J. Supercrit. Fluids 10: 156-168. http://dx.doi.org/10.1016/S0896-8446(97)00014-4

Ristíc MD, Duletić-Lausević S, Knezević-Vukcević J, Marin PD, et al. (2000). Antimicrobial activity of essential oils and ethanol extract of Phlomis fruticosa L. (Lamiaceae). Phytother. Res. 14: 267-271. http://dx.doi.org/10.1002/10991573(200006)14:4<267::AID-PTR644>3.0.CO;2-7

Shen Y, Sun Y, Sang Z, Sun C, et al. (2012). Synthesis, characterization, antibacterial and antifungal evaluation of novel monosaccharide esters. Molecules 17: 8661-8673. http://dx.doi.org/10.3390/molecules17078661

Simić A, Soković MD, Ristić M, Grujić-Jovanović S, et al. (2004). The chemical composition of some Lauraceae essential oils and their antifungal activities. Phytother. Res. 18: 713-717. http://dx.doi.org/10.1002/ptr.1516

Urzúa A, Modak B, Santander R, Heit C, et al. (2013). Insecticidal properties of Heliotropium stenophyllum essential oil on the house fly, Musca domestica L. Bol. Latinoam. Caribe Plantas Med. Aromat. 12: 196-200.

Genetics and Molecular Research 16 (2): gmr16029548 
Xie Z, Liu Q, Liang Z, Zhao M, et al. (2013). The GC/MS analysis of volatile components extracted by different methods from Exocarpium citri grandis. J. Anal. Methods Chem. 2013: 918406. http://dx.doi.org/10.1155/2013/918406

Zorca M, Găinar I and Bala D (2006). Supercritical $\mathrm{CO}_{2}$ extraction of essential oil from coriander fruits. Anal. Univ. Buc. -. Chimie 2: 79-83.

Zrira S, Elamrani A, Pellerin A, Bessière JM, et al. (2008). Isolation of Moroccan Ammi visnaga oil: comparison between hydrodistillation, steam distillation and supercritical fluid extraction. J. Essent. Oil Bear. Plants 11: 30-35. http:// dx.doi.org/10.1080/0972060X.2008.10643593

Genetics and Molecular Research 16 (2): gmr16029548 